\title{
My Life as an Account in the Single Digits
}

Allen's with Clarissa but wants to handle Leslie, slip some skin under the nail, a slight squeeze $\&$ shuffle inside her shirt. The saliva thickens when a tongue goes down \& Allen doesn't have the guilt: Lewis fingered Leslie, paces in his cage as Thursday drops a shoulder from the effigy. We weren't so fucking pretentious, two paddles without a boat, but Ian wants Chinese, exotic, settles for a slice unheated, smoke uncurled blue. Allen peels a lamp inside his window. He never loved the dirt the way he loves an easy neck: Lewis slept with Lila, after all, the lyric on his feet, Lila on her knees between a split of rouge \& genius. Could is beside the point. Between if you're alone. Allen desperately needs his early 20s, Leslie's mouth when whiskey wets her lips. She's soaked in rain if rain can counterfeit a hue, a thread inside a bulb for the night, without the view \& cry of Sunday. 